\title{
Changes in LH pulse frequency and serum progesterone concentrations during the transition to breeding season in ewes
}

\author{
H. I'Anson and S. J. Legan \\ Department of Physiology and Biophysics, University of Kentucky, Lexington, $K Y$ 40536-0084, \\ U.S.A.
}

\begin{abstract}
Summary. To characterize the changes in LH pulse frequency during the transition to breeding season, LH pulse patterns and serum progesterone profiles were determined in 8 intact ewes from mid-anoestrus to the early breeding season. Overall, 8 increases in LH pulse frequency were observed and these were restricted to 5 ewes. Of the 8 increases, 7 occurred during the 4 weeks before the first cycle, 5 of them within 1 week after a pulse frequency typical of anoestrus $(0-2$ per $8 \mathrm{~h})$. Six of them occurred less than 1 week before either a full-length luteal phase $(n=2)$ or a 1-3-day increment in progesterone $(n=4)$. Seven of these brief progesterone increases were observed in 6 ewes, 5 of them immediately preceding the first full-length luteal phase. These results are consistent with the hypothesis that the seasonal decrease in response to oestradiol negative feedback at the beginning of the breeding season causes an increase in GnRH, and thereby LH pulse frequency. In addition, they demonstrate that the first increase in tonic LH secretion occurs in $<1$ week and, in most ewes, initiates either the first fulllength cycle or a transient increase in progesterone, the latter occurring more often.
\end{abstract}

Keywords: LH; pulse frequency; progesterone; seasonal transition; short luteal phase; ewes

\section{Introduction}

It has been proposed that onset of the breeding season in ewes is caused by a decrease in the negative feedback action of oestradiol on tonic gonadotrophin secretion (Legan et al., 1977). Further, it has been suggested that the seasonal decrease in the negative feedback action of oestradiol on the hypothalamic pulse generator causes an increase in GnRH, and thereby LH, pulse frequency (Karsch, 1980; Goodman \& Karsch, 1981). This hypothesis is supported by the finding that, in ovariectomized ewes, oestradiol decreases LH pulse frequency in anoestrus, but not in the breeding season (Goodman et al., 1982), and by the observations that GnRH pulses in ewes are highly correlated with LH pulses (Clarke \& Cummins, 1982; Levine et al., 1982). The latter hypothesis is also supported by the observation that, in intact ewes, LH pulse frequency is approximately 1 per $8 \mathrm{~h}$ in anoestrus (Scaramuzzi \& Baird, 1977; Yuthasastrakosol et al., 1977; McLeod et al., 1982a, b; Legan et al., 1985a), whereas during the oestrous cycles of the breeding season it ranges from 1 per $4 \mathrm{~h}$ in the luteal phase, to more than 1 per $\mathrm{h}$ during the late follicular phase (Baird, 1978; Karsch et al., 1983). In addition, if the LH pulse frequency is increased during anoestrus to 1 per $2 \mathrm{~h}$, a frequency similar to that of the early follicular phase, by pulsatile administration of synthetic GnRH for up to 80 days, successive oestrous cycles can be initiated (McNatty et al., 1982).

Based on the observation that LH pulse frequency is increased 10 days, but not 20 days, before the first ovulation (Walton et al., 1980), it may be proposed that the seasonal decrease in response to oestradiol negative feedback, which initiates the preovulatory events, occurs within 10 days. The findings that pulsatile administration of GnRH to anoestrous ewes at low to intermediate follicular phase frequencies can initiate cycles rapidly, within 2-3 days (McNatty et al., 1982; McLeod et al., 
1982a, b; McLeod \& Haresign, 1984; Legan et al., 1985a, b), strongly suggest that the first increase in $\mathrm{LH}$ pulse frequency at the end of anoestrus may occur within a few days. Such a rapid change in response to oestradiol negative feedback would contrast markedly with the steroid-independent seasonal change in LH pulse frequency observed in ovariectomized ewes, which takes place over several months (Robinson et al., 1985). Therefore, the following study was designed to determine how rapidly the increase in LH pulse frequency at the onset of the breeding season occurs, and when it happens in relation to the first luteal phase.

\section{Materials and Methods}

Animals. Eight Suffolk or Suffolk-crossbred ewes, weighing $63.6 \pm 2.8 \mathrm{~kg}$ at 7 weeks before beginning this study, were maintained outdoors on pasture or in a dry lot. During sampling periods, they were housed in three-sided sheds. When housed on the dry lot, the ewes were fed hay. All animals were given $0.22 \mathrm{~kg}$ grain daily and water was supplied ad libitum. No rams were present at any time during this study.

Experimental procedure and blood samples. To determine when and how rapidly the increase in LH pulse frequency occurs during the transition to the breeding season, blood samples $(3 \mathrm{ml})$ were obtained by jugular puncture every $15 \mathrm{~min}$ for $8 \mathrm{~h}$, every 2 weeks in late anoestrus from 25 June to 6 August. Thereafter, this frequent sampling regimen was repeated weekly until 30 September, by which time all ewes had entered the breeding season. To establish occurrence of the first luteal phase of the breeding season, serum progesterone concentrations were measured in blood samples $(7 \mathrm{ml})$ obtained twice weekly from 25 June to 30 July and three times weekly thereafter until onset of the breeding season ( 30 September, last day of sampling in all ewes).

Blood samples were stored overnight at $4^{\circ} \mathrm{C}$. Sera were then separated and stored at $-20^{\circ} \mathrm{C}$ until assayed.

Radioimmunoassays. LH concentrations were determined in duplicate in 2.5-200 $\mu$ l samples of serum by means of a radioimmunoassay (Niswender et al., 1969) modified as described previously (Legan et al., 1985a). The limit of detection ( $95 \%$ confidence limit of maximum binding) averaged $0.11 \mathrm{ng} / \mathrm{ml}$ for $200 \mu \mathrm{l}$ serum. The intra- and interassay coefficients of variation (CV) for $200 \mu$ l samples of a serum pool containing $1.08 \mathrm{ng} \mathrm{LH} / \mathrm{ml}(n=8)$, which inhibited binding of labelled ligand to $49 \cdot 4 \%$, averaged $7 \cdot 3 \%$ and $9 \cdot 8 \%$, respectively. LH concentrations were expressed in terms of NIAMDD ovine LH reference preparation, Batch 21, which has a potency of 1.86 times that of NIH-LH-S12, as we determined by radioimmunoassay.

Progesterone concentrations were measured in duplicate petroleum ether extracts of $200 \mu \mathrm{l}$ serum by a modification (Legan et al., 1985a) of a radioimmunoassay described previously (Gibori et al., 1977). Assay sensitivity (95\% confidence limits of maximum binding) averaged $0.0 \mathrm{I} \mathrm{ng} /$ tube, and ether and water blanks were routinely below this value. The intra- and inter-assay CVs averaged 12 and $17 \%(n=16)$, respectively, for $100 \mu l$ samples of a serum pool from intact ewes which inhibited binding of labelled ligand to about $41 \%$ and contained $3.45 \mathrm{ng}$ progesterone $/ \mathrm{ml}$.

Identification of LH pulses. A pulse of LH was defined by the criteria of Goodman \& Karsch (1980), namely: (1) a peak had to occur within two samples of the preceding nadir, (2) the amplitude (peak minus preceding nadir) had to be greater than the sensitivity of the LH assay, and (3) the peak LH level had to exceed the $95 \%$ confidence limits of the preceding and subsequent nadirs. Confidence limits for the LH concentration in each sample were determined by the method of Duddleson et al. (1972). Basal LH concentrations are defined as all values within $95 \%$ confidence limits of a pulse nadir. Pulse amplitude is the difference between the peak LH concentration during the pulse and the preceding nadir. Interpulse interval is the duration between 2 pulse peaks.

Statistical analysis. Statistical analyses were performed using within-subjects, repeated measures analysis of variance (BMDP Statistical Software, 1983; SAS Institute, Inc., USA) with time as the repeated measures factor. Data were square-root-transformed whenever Bartlett's test (Snedecor \& Cochran, 1967) indicated that variances were not homogeneous. When there was a significant main effect at the 0.05 level, Newman-Keuls post-hoc tests were performed when appropriate. Undetectable hormone concentrations were assigned a value equivalent to the limit of detection of the assay.

\section{Results}

\section{Pulsatile LH patterns}

Representative pulse patterns from 4 ewes are illustrated in Fig. 1. In 46 of 59 frequent sampling periods before the first full-length luteal phase, LH pulse frequencies were 0,1 or 2 per $8 \mathrm{~h}$, the frequency averaging $0.98 \pm 0.10$ pulses per $8 \mathrm{~h}$ (mean \pm s.e.m., 8 ewes), and the amplitude averaging $3.97 \pm 0.62 \mathrm{ng} / \mathrm{ml}$ ( 8 ewes) (Fig. 1, left column; Fig. 2, open triangles). Indeed, $83 \%$ of the time, LH pulse frequency was only 0 or 1 per $8 \mathrm{~h}$ (Table 1), pulse frequencies of 2 per $8 \mathrm{~h}$ occurring randomly throughout anoestrus. Basal $\mathrm{LH}$ concentrations between pulses in anoestrus remained 


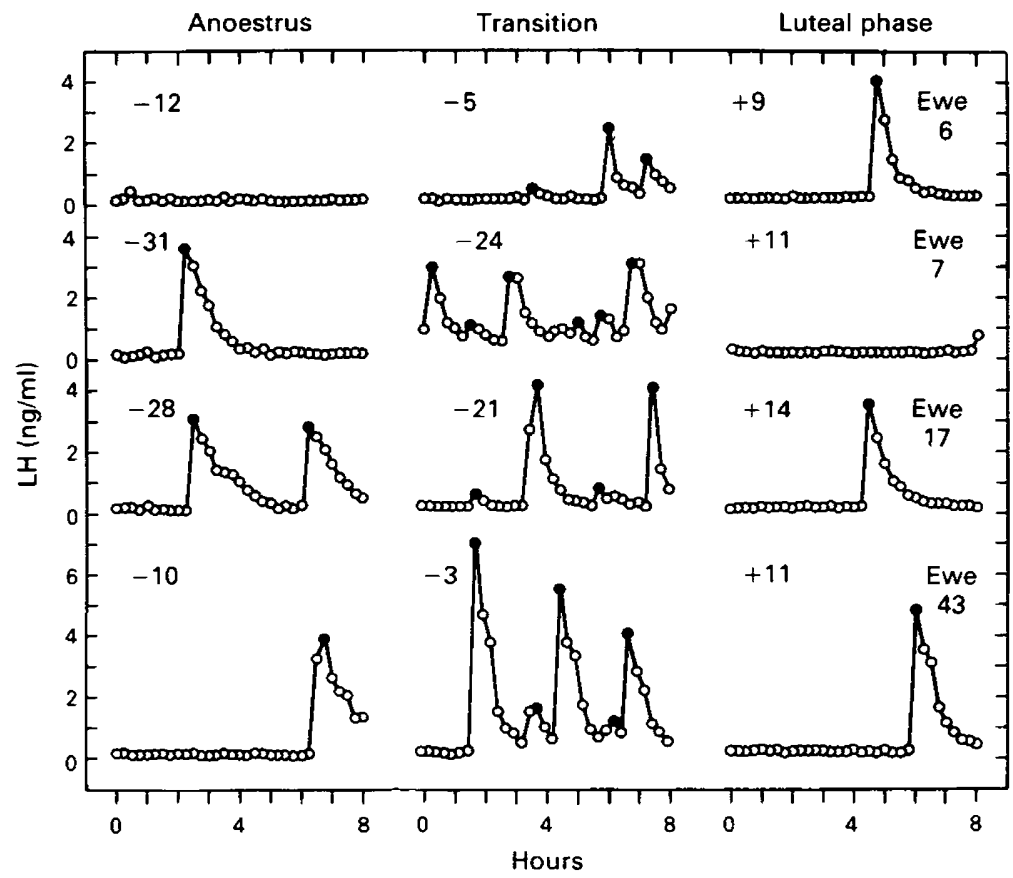

Fig. 1. LH pulse frequency from mid-anoestrus to the breeding season. Serum LH concentrations in samples obtained every $15 \mathrm{~min}$ for $8 \mathrm{~h}$ in 4 individual ewes on 3 representative occasions are illustrated. LH pulse frequencies of $\leq 2$ per $8 \mathrm{~h}$, or $\geq 3$ per $8 \mathrm{~h}$ are depicted in the left (anoestrus) and middle (transition) columns, respectively. Each anoestrous pulse pattern was observed 1 week before the respective transition pattern. On the right, LH pulse patterns during the first full-length luteal phase of the breeding season (luteal phase) are illustrated. The LH pulse peaks are depicted by closed circles. The day of each sampling period from the beginning of the first full-length cycle is indicated in the upper left of each panel.

low $(0.26 \pm 0.02 \mathrm{ng} / \mathrm{ml}, 8$ ewes $)$. On one occasion in this study, a pulse frequency of 3 per $8 \mathrm{~h}$ was observed during anoestrus (Ewe 21).

The pulse frequency typical of anoestrus ranged from 0 to 2 pulses per $8 \mathrm{~h}$, as indicated by additional observations made on 114 of 115 other occasions of frequent sampling in anoestrous Suffolk ewes during a 4-year period. In the remaining sampling period pulse frequency was 3 per $8 \mathrm{~h}$. Amongst these 115 frequent sampling periods, frequencies of 0,1 and 2 pulses per $8 \mathrm{~h}$ were observed on 22, 41 and 11 occasions, respectively, and frequencies of 0,1 and 2 pulses per $6 \mathrm{~h}$ were observed on 13, 20 and 7 occasions, respectively, 18 of the latter having been reported previously (Legan et al., 1985b). Instances of 2 pulses per 6 or $8 \mathrm{~h}$ always occurred randomly throughout anoestrus, and no clustering of pulses was observed. Mean pulse frequency during anoestrus was not different from year to year, and averaged $0.79 \pm 0.10(n=48), 1.00 \pm 0.12(n=12)$, and $1.07 \pm 0.21(n=15)$ pulses per $8 \mathrm{~h}$, and $0.85 \pm 0.11(n=40)$ pulses per $6 \mathrm{~h}$. The daytime anoestrous pulse frequency is therefore $0-2$ pulses per $8 \mathrm{~h} 99 \%$ of the time.

An increase in pulse frequency to 3 or more pulses per $8 \mathrm{~h}$ was observed during 7 of the 59 frequent sampling periods in 4 of the 8 ewes within 4 weeks before the first full-length luteal phase (3.86 \pm 0.46 pulses per $8 \mathrm{~h}$, range $=3-6,4$ ewes) (Fig. 2, closed triangles; Table 1). Four of these instances of increased pulse frequency are depicted in Fig. 1 (middle column), and the remaining 3 increases, which are not illustrated in Fig. 1, resemble those of Ewes 6, 7 and 43 in Fig. 1, each being 3 per $8 \mathrm{~h}$. No increase in LH pulse frequency was observed in the remaining 4 ewes during these 4 weeks. Mean basal LH concentrations between pulses tended to be elevated during these periods of 
increased pulse frequency (anoestrus $v s$ periods of increased frequency, $0.24 \pm 0.02$ vs $0.52 \pm 0.14 \mathrm{ng} / \mathrm{ml}$, range $=0.23-0.29 \mathrm{ng} / \mathrm{ml}$ in anoestrus and $0.26-0.78 \mathrm{ng} / \mathrm{ml}$ in transition, 4 ewes). Small-amplitude pulses $(\leqslant 1.00 \mathrm{ng} / \mathrm{ml})$ were often interspersed among larger pulses. Such wide variability in pulse amplitude was not observed in any of the other 51 frequent sampling periods, due to the absence of such small-amplitude pulses during anoestrus or in the presence of elevated progesterone concentrations. Finally, mean pulse amplitude during periods of increased pulse frequency was lower than that during anoestrus $(2.00 \pm 0.36 \mathrm{ng} / \mathrm{ml}$ vs $4 \cdot 16 \pm 0.40 \mathrm{ng} / \mathrm{ml}, 4$ ewes, $P<0.05$ ).

During the remaining 5 of the 59 frequent sampling periods before the first full-length luteal phase, a frequency of $0-2$ per $8 \mathrm{~h}$ was observed in the presence of elevated serum progesterone concentrations $(>0.80 \mathrm{ng} / \mathrm{ml}, n=4)$ (Fig. 2, stippled triangles before Day 0 ), or an LH surge occurred (Fig. 2, Ewe 21) (Table 1).

When the frequent sampling periods occurred during luteal phases, LH pulse frequency was similar to that during anoestrus ( $1.00 \pm 0.26$ pulses per $8 \mathrm{~h}, 8$ ewes, Fig. 1, right column; Fig. 2, stippled triangles), while LH pulse amplitude was lower $(2.52 \pm 0.40$ vs $4.28 \pm 0.62 \mathrm{ng} / \mathrm{ml}$, $P<0.05, n=7$ ewes, 1 ewe having no pulses).

\section{Progesterone patterns}

Serum progesterone concentrations remained low in all 8 ewes $(0.18 \pm 0.05 \mathrm{ng} / \mathrm{ml})$ until at least 20 days before the first full-length luteal phase (Fig. 2). During the next 3 weeks, there were a total of 7 transient rises in progesterone, averaging $0.95 \pm 0.14 \mathrm{ng} / \mathrm{ml}$, which were observed in at least 1 sample in 6 of the 8 ewes ( 1 rise per ewe in 5 ewes, and 2 rises in 1 ewe). Five of these transient increases in progesterone occurred within 5 days of the onset of the first full-length luteal phase (Ewes 17, 21, 26, 42 and 43). In Ewe 17 there was a second similar progesterone rise 15 days before the first oestrous cycle. In Ewe 7, a brief rise in progesterone occurred around Day - 20, after which progesterone concentrations remained basal until the first full-length luteal phase. In the 2 ewes in which transient rises in progesterone were not observed, either no increase in progesterone was detected (Ewe 6) or a solitary luteal phase occurred (Ewe 27) before the onset of successive, uninterrupted cycles.

The mean date of onset of the breeding season (onset of first cycle) was 3 September \pm 3 days $(n=8)$, which was similar to that reported previously for Suffolk ewes ( 3 September \pm 5 days; Robinson \& Karsch, 1984).

\section{Relationship between $\mathrm{LH}$ and progesterone profiles}

Seven of the 8 instances of increased LH pulse frequency ( $\geq 3$ per $8 \mathrm{~h}$ ) were observed during the 4 weeks preceding the first full-length cycle of the breeding season, the remaining one occurring 10 weeks before the first cycle (Fig. 2, closed triangles). Five occasions of increased frequency were observed in 2 animals ( 3 in Ewe 7, and 2 in Ewe 17), and 1 each occurred in 3 of the remaining ewes (Ewes 6, 21, and 43). In addition, 6 of them occurred $<1$ week before a rise in progesterone, suggesting that they may have initiated the events leading to an LH surge. This possibility is supported by the finding that, although the sampling regimen limited our ability to detect $\mathrm{LH}$ surges, 2 surges were observed during the frequent sampling periods, one before the first full-length luteal phase (Ewe 17), and the other just before a transient rise in progesterone (Ewe 21) (mean \pm s.e.m. LH concentrations for $8 \mathrm{~h}: 31.30 \pm 3.42$ and $14.07 \pm 3.70 \mathrm{ng} / \mathrm{ml}$, respectively). Further, when anoestrous mean basal $\mathrm{LH}$ concentrations, LH pulse amplitude and pulse frequency were normalized to the first rise in progesterone, whether it be a transient increase or a full-length luteal phase, LH pulse frequency increased during the week before the first rise in progesterone $(P<0.001)$ (Fig. 3). At the same time, pulse amplitude decreased $(P<0.005)$, whereas mean $\mathrm{LH}$ levels did not change before onset of the breeding season $(P>0 \cdot 05)$. 


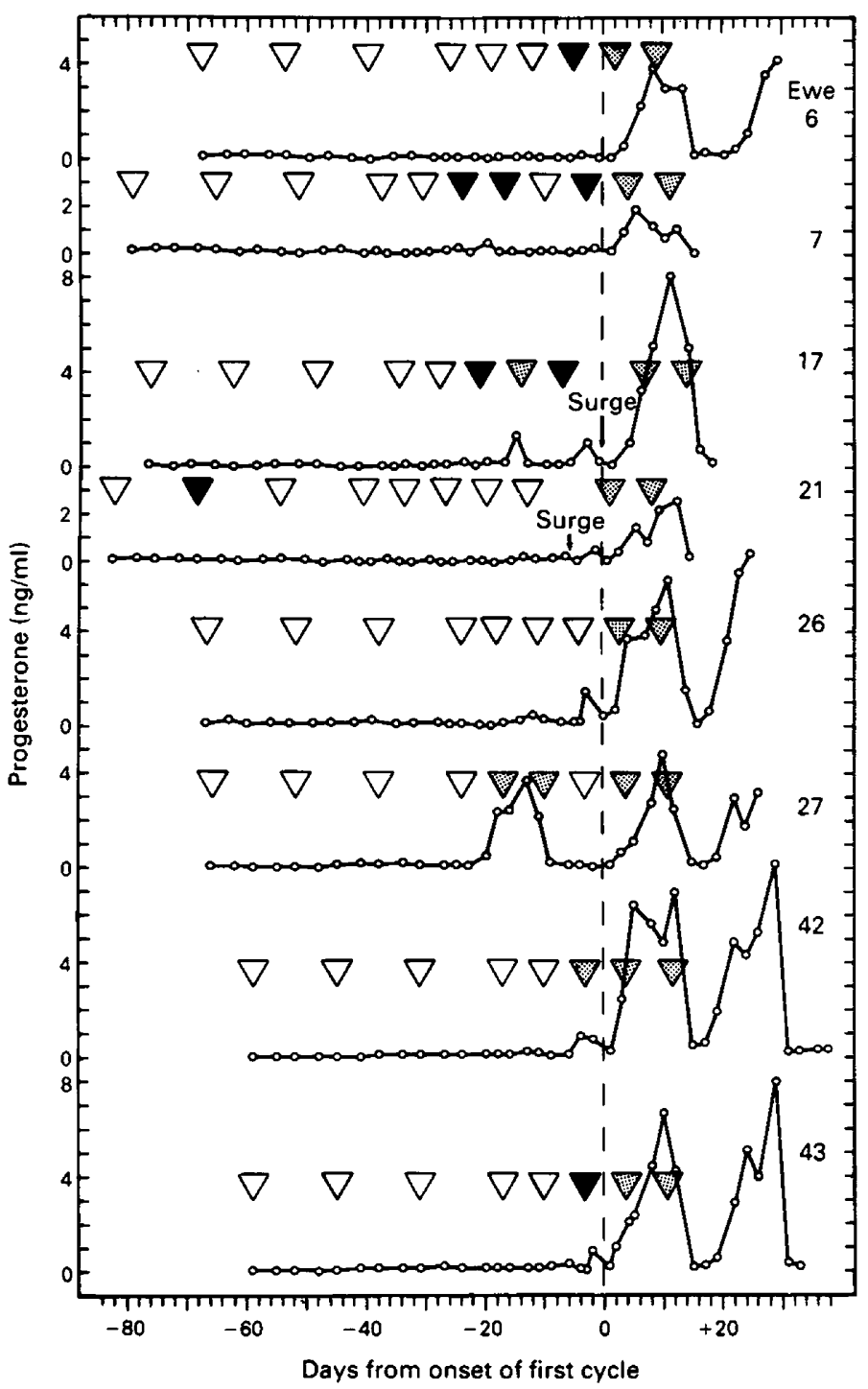

Fig. 2. Correlation between increasing LH pulse frequency and serum progesterone concentrations during the transition to breeding season. Serum progesterone concentrations in samples obtained 2-3 times weekly from 8 ewes between mid-anoestrus and onset of the breeding season are shown. The vertical broken line indicates the day of onset of the first full-length oestrous cycle of the breeding season, estimated from the serum progesterone pattern. Triangles depict days on which $\mathrm{LH}$ pulse frequency was determined in samples obtained every $15 \mathrm{~min}$ for $8 \mathrm{~h}: \nabla=\mathrm{LH}$ pulse frequencies of $\leq 2 \operatorname{per} 8 \mathrm{~h} ; \nabla=\geq 3 \operatorname{per} 8 \mathrm{~h} ; \quad=\leq 3 \operatorname{per} 8 \mathrm{~h}$ in the presence of elevated progesterone. Detection of LH surges during a frequent sampling period in Ewes 17 and 21 is indicated.

In 5 instances, the increase in LH pulse frequency occurred within 1 week after a low-frequency anoestrous pulse pattern (Fig. 2, open triangles followed by a closed triangle 1 week later). Only 1 occasion of increased pulse frequency during the 4 weeks preceding the first full-length luteal phase was preceded by a maximal anoestrous pulse frequency of 2 per $8 \mathrm{~h}$. In this case, LH pulse frequency doubled to 4 pulses per $8 \mathrm{~h}$ (Fig. 1, Ewe 17). In the 6 remaining cases, pulse frequency was 
Table 1. Incidence of LH pulse frequencies or LH surges before onset of the first cycle in ewes

\begin{tabular}{lcccccccc}
\hline & & Anoestrus & & Transition & Progesterone* $^{*}$ & Surge & Total \\
\hline $\begin{array}{l}\text { Pulse frequency, } \\
\text { pulses per 8 } \mathrm{h}\end{array}$ & 0 & 1 & 2 & 3 & $3-6$ & $0-2$ & - & - \\
$\begin{array}{l}\text { No. of sampling } \\
\text { periods }\end{array}$ & 8 & 30 & 8 & 1 & 7 & 4 & 1 & 59 \\
\hline
\end{tabular}

*Pulse frequencies $\leq 2$ per $8 \mathrm{~h}$ in the presence of elevated progesterone.

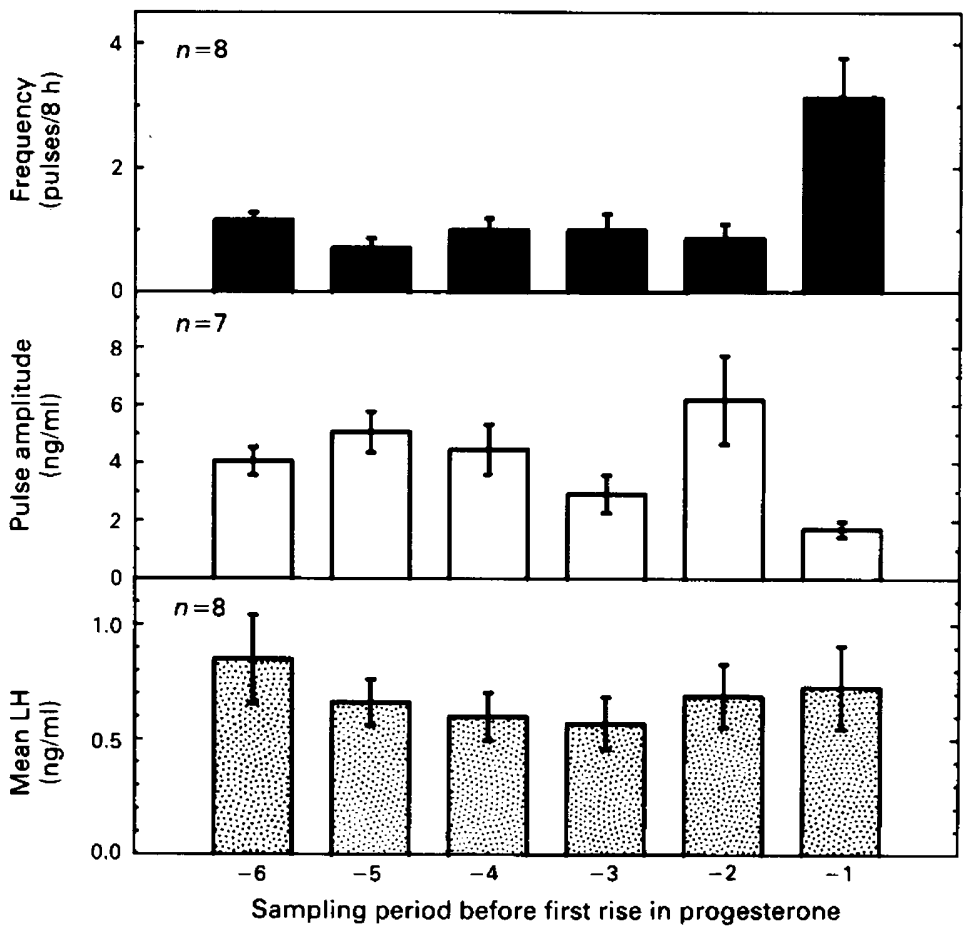

Fig. 3. Mean ( \pm s.e.m.) basal serum LH concentrations, LH pulse amplitude and LH pulse frequency during the 6 frequent sampling periods before the first rise in progesterone. The mean LH pulse frequency in sampling period -1 is different from that in the other 5 sampling periods $(P<0.05)$, which are not different from each other $(P>0.05)$. The mean pulse amplitude in sampling period -1 is different from that in periods $-2,-4,-5$ and $-6(P<0.05)$, and the mean amplitudes in sampling periods -2 through -6 are not different from each other $(P>0.05)$. Mean LH values did not change $(P>0.05)$.

at least tripled within 1 week after an anoestrous pulse frequency, indicating that the increase occurred within 1 week.

When LH pulse frequency increased more than 1 week before onset of the first full-length cycle, it was not sustained throughout this period. In 3 ewes, a subsequent decrease in pulse frequency to 
levels characteristic of anoestrus was observed between the first increase in pulse frequency and the first cycle (Fig. 2, Ewes 7, 17 and 21).

Finally, with 2 exceptions, whenever progesterone concentrations increased above $0.34 \mathrm{ng} / \mathrm{ml}$, LH pulse frequency was low, regardless of whether the progesterone elevation constituted part of a transient rise or a luteal phase (Fig. 2, stippled triangles). Both exceptional cases occurred during the early part of the first full-length luteal phase when progesterone concentrations were beginning to rise, but LH pulse frequency was 3 per $8 \mathrm{~h}$ (Fig. 2, Ewes 6 and 43, first stippled triangle during first luteal phase). On these 2 occasions, however, the inter-pulse intervals and basal LH concentrations were more characteristic of those observed during anoestrus or a luteal phase.

\section{Discussion}

According to one current hypothesis for the endocrine control of the transition to breeding season, a photoperiodically-induced decrease in response to oestradiol negative feedback allows an increase in $\mathrm{GnRH}$, and thereby $\mathrm{LH}$ pulse frequency which triggers the preovulatory events leading to the first cycle of the breeding season (Karsch, 1980). If LH pulse frequency either remains increased or continues to rise for 48-60 h, the length of a follicular phase, then the increase in tonic $\mathrm{LH}$ secretion and the resulting rise in oestradiol would induce an LH surge, and the first ovulation of the breeding season would occur. This hypothesis is strengthened by the numerous demonstrations of induction of an LH surge within $48 \mathrm{~h}$ after a continual or sustained increase in LH (McNeilly et al., 1982) or GnRH pulse frequency in anoestrous ewes (McLeod et al., 1982a, b; McNatty et al., 1982; Legan et al., 1985a, b). In most anoestrous ewes, as few as 11 exogenous LH pulses, in addition to the endogenous pulses occurring every $8 \mathrm{~h}$, can initiate an LH surge in $48 \mathrm{~h}$ (Legan et al., 1985a), suggesting that an increase in LH pulse frequency would induce a surge if sustained for only 2 days. Finally, our finding that 6 of the 8 observed increases in LH pulse frequency occurred within 1 week after a low-frequency pattern of secretion and within 1 week before a rise in progesterone, also supports the hypothesis that an increase in tonic $\mathrm{LH}$ secretion initiates the sequence of preovulatory events leading to the first LH surge of the breeding season.

Although we only sampled for $8 \mathrm{~h}$ weekly, the mean anoestrous LH pulse frequency reported herein is similar to those observed in several other breeds of anoestrous ewes sampled every 20 min for $36 \mathrm{~h}$ (inter-pulse interval, $472 \pm 45 \mathrm{~min}, 7$ ewes) (Martin et al., 1985), for $24 \mathrm{~h}$ (Yuthasastrakosol et al., 1977), or every $15 \mathrm{~min}$ for 12 or $36 \mathrm{~h}$ (McLeod et al., 1982a, b). In addition, the incidence of pulse frequencies of $0,1,2$ or 3 per $8 \mathrm{~h}$ is similar among all these studies. Furthermore, since there is no diurnal variation in pulse frequency, and pulses are randomly distributed throughout the day in anoestrous ewes (Martin et al., 1985), the increase in pulse frequency we observed cannot be attributed to a lack of precision of measurement or random biological variation.

An increase in $\mathrm{LH}$ pulse frequency was detected in only 4 of the 8 ewes in which pulse patterns were monitored. If one assumes, however, that the increase in pulse frequency must be sustained for only 2 days before induction of an LH surge, and there are 5 weeks during which it may occur (time between first LH surge at end of anoestrus in earliest and latest ewes to start cycling, Ewes 27 and 21 , respectively), binomial probability theory predicts that, by sampling weekly in 8 ewes, the increase in frequency would most likely be detected in 3 ewes (Byrkit, 1975). Thus, based on these considerations, the observation of 1 or more increases in LH pulse frequency shortly before the first full-length luteal phase in 4 of 8 ewes supports the foregoing hypothesis.

During the periods of increased frequency, low-amplitude pulses were interspersed among the larger ones, therefore mean pulse amplitude decreased. Similar low-amplitude pulses have been observed in the breeding season at times of high pulse frequency, e.g. during the follicular phase (Karsch et al., 1983), and in untreated ovariectomized ewes (Karsch, 1980). In contrast, they have not been observed in anoestrous ovariectomized ewes, in which pulse frequency is also high (Goodman \& Karsch, 1981). In addition, during the follicular phase, a decrease in mean pulse amplitude accompanies the increase in frequency (Karsch et al., 1983). These observations suggest 
that the periods of increased pulse frequency during the 4 weeks before the first full-length luteal phase may be part of the first follicular phases of the breeding season.

The foregoing results also demonstrate that a change in LH pulse frequency was not detected throughout anoestrus, suggesting that the change in LH pulse frequency which initiates the breeding season is relatively fast, from $0.98 \pm 0.10$ to $3.86 \pm 0.46$ pulses per $8 \mathrm{~h}$ in $<1$ week. This finding is consistent with the observation that the seasonal decrease in response to negative feedback in oestradiol-treated ovariectomized ewes takes place, for the most part, within 1 week in individual ewes (Legan et al., 1977). Such rapid changes in the steroid-dependent mechanism governing tonic LH secretion are in striking contrast to the gradual modulations in the steroid-independent control of LH secretion. For example, in untreated ovariectomized ewes, LH pulse frequency changes gradually, from 7.20 to 12.00 pulses per $8 \mathrm{~h}$ in 4 months (July to October), in close association with the annual cycle of daylength (Robinson et al., 1985). The relative roles of the steroid-dependent and the steroid-independent 'direct-drive' mechanisms during the transition to the breeding season therefore remain to be determined. However, the rapidity with which LH pulse frequency increases in intact animals during the transition to the breeding season in this study (i.e. steroid-dependent mechanism), and the temporal dissociation between the changes in steroid feedback and the level of direct photoperiodic drive (Robinson et al., 1985), suggest that the oestradiol-dependent control system modulates tonic $\mathrm{LH}$ secretion by a different mechanism from the steroid-independent effects of photoperiod.

There appears to be a transition period before the first full-length cycle, lasting 1-4 weeks in most ewes, and during which the oestradiol negative feedback mechanism can change from a closed-loop to an open-loop mode of operation (Legan \& Karsch, 1979). The foregoing data also suggest that the decrease in response to oestradiol negative feedback is not always sustained, but rather may fluctuate between a closed-and open-loop mode one or more times before remaining 'open' throughout the breeding season. This latter conclusion is based on the observation that 2 or more increases in $\mathrm{LH}$ pulse frequency, separated by a rise in progesterone or an anoestrous $\mathrm{LH}$ pulse frequency, were detected in 2 ewes (Ewes 7 and 17) during the 4-week transition period. The decrease in LH pulse frequency between the 2 instances of increased frequency may reflect the negative feedback action of progesterone on the hypothalamic pulse generator (Goodman \& Karsch, 1980; Goodman et al., 1981) or a short-lived rebound in the response to oestradiol negative feedback.

The atypical increase in LH pulse frequency, which occurred about 10 weeks before onset of cycles in Ewe 21, and which was characterized by higher amplitude pulses than those normally observed during the follicular phase, may have been caused by stress or some other stimulus which is not part of the mechanism controlling onset of the breeding season.

These results support previous demonstrations that brief increments in progesterone occur just before the first full-length luteal phase of the breeding season (Yuthasastrakosol et al., 1975; Walton et al., 1977). In addition, the present results demonstrate that one or more of these brief rises in progesterone can occur within $1-4$ weeks before the first full-length luteal phase, the same time interval as the previously-defined transition period, during which one or more increases in LH pulse frequency were observed. In most instances, these increases in progesterone only last 1-3 days and attain a maximum of about $1 \mathrm{ng} / \mathrm{ml}$. Transient, low-amplitude increases in progesterone have also been observed before the first cycle at puberty in lambs (Foster \& Ryan, 1979; Berardinelli et al., 1980; Keisler et al., 1983; Foster et al., 1986), heifers (Gonzalez-Padilla et al., 1975) and primates (Dierschke et al., 1974; Foster, 1977), after pulsatile administration of GnRH to anoestrous ewes (Legan et al., 1985a; Hunter et al., 1986), after a ram-induced LH surge in anoestrous ewes (Pearce et al., 1985), at the end of post-partum anoestrus in cows (Pope et al., 1969), and at onset of the breeding season in dairy goats (BonDurant et al., 1981). They are therefore a common phenomenon of the initiation of cyclicity in at least these 4 species.

Full-length luteal-phase patterns of serum progesterone immediately succeeded 5 of the 7 transient increases in progesterone. This finding suggests that the antecedent rise in progesterone 
may ensure that a full-length luteal phase follows the next LH surge. Additional evidence is provided by the demonstration that an antecedent transient rise in progesterone increases incidence of full-length luteal phases to $100 \%$ following induction of an LH surge in anoestrous ewes (Oldham \& Martin, 1978; Legan et al., 1985b). Progesterone may therefore play an important role during the transition to breeding season by ensuring onset of full-length cycles, as has been demonstrated in anoestrus.

What causes the increases in progesterone which occur during the 4 weeks before the first cycle? Based on the observations that such brief rises in progesterone at puberty and in anoestrus are caused by an LH surge (Ryan \& Foster, 1978; Legan et al., 1985a, b; Foster et al., 1986), and that they are associated with structures which macroscopically resemble corpora lutea (Oldham \& Martin, 1978; Keisler et al., 1983; Legan et al., 1985b), they may be caused by LH surges. This possibility is supported by the observation that serum LH concentrations $>20 \mathrm{ng} / \mathrm{ml}$ were observed in a daily sample obtained in each of 3 ewes about 1 week before the first full-length luteal phase (Yuthasastrakosol et al., 1975), and by the finding reported herein of an LH surge in < 1 week before a short luteal phase (Ewe 21). Therefore the brief increments in progesterone during the transition to breeding season may represent short or full-length luteal phases, which result from ovulation of immature or mature follicles, respectively. If this is not the case, and an LH surge does not precede each short luteal phase, the short luteal phase may represent luteinization of follicles which have only been exposed to an increase in $\mathrm{LH}$ pulse frequency, without a subsequent preovulatory surge.

In 2 ewes (Nos 7 and 21), no increase in progesterone occurred within 4-5 days after an increase in LH pulse frequency, indicating that the resultant rises in LH and oestradiol secretion may not have been sustained long enough to trigger an LH surge. Alternatively, the sampling frequency was too low in these 2 instances to detect a transient rise in progesterone. Therefore, it remains to be determined whether each increase in LH pulse frequency during the transition to the breeding season is sustained long enough to induce an $\mathrm{LH}$ surge.

The foregoing observations lead to a modification of the current model describing the beginning of the breeding season in sheep to include a transition period of $1-4$ weeks before the first oestrous cycle, during which 1 or more increases in LH pulse frequency and serum progesterone concentrations may occur.

We thank Dr Gordon D. Niswender and Dr Leo E. Reichert, Jr, for providing reagents for radioimmunoassay; Ms Marilee Van Arsdall, Ms Christine Gatus; and Ms Teresa Howard for invaluable technical assistance. This work was supported by NIH-HD-14039 and NSF-PCM8302959.

\section{References}

Baird, D.T. (1978) Pulsatile secretion of $\mathbf{L H}$ and ovarian estradiol during the follicular phase of the sheep estrous cycle. Biol. Reprod. 18, 359-364.

Berardinelli, J.G., Dailey, R.A., Butcher, R.L. \& Inskeep, E.K. (1980) Source of circulating progesterone in prepubertal ewes. Biol. Reprod. 22, 233-236.

BonDurant, R.H., Darien, B.J., Munro, C.J., Stabenfeldt, G.H. \& Wang, P. (1981) Photoperiod induction of fertile oestrus and changes in LH and progesterone concentrations in yearling dairy goats (Capra hircus). J. Reprod. Fert. 63, 1-9.

Byrkit, D.R. (1975) In Elements of Statistics, pp. 105-11. Van Nostrand Reinhold, New York.

Clarke, I.J. \& Cummins, J.T. (1982) The temporal relationship between gonadotropin releasing hor- mone (GnRH) and luteinizing hormone (LH) secretion in ovariectomized ewes. Endocrinology 111, $1737-1739$.

Dierschke, D.J., Weiss, G. \& Knobil, E. (1974) Sexual maturation in the female Rhesus monkey and the development of estrogen-induced gonadotropic hormone release. Endocrinology 94, 198-206.

Duddleson, W.G., Midgley, A.R., Jr \& Niswender, G.D. (1972) Computer program sequence for analysis and summary of radioimmunoassay data. Comput. Biomed. Res. 5, 205-217.

Foster, D.L. (1977) Luteinizing hormone and progesterone secretion during sexual maturation of the Rhesus monkey, short luteal phases during the initial menstrual cycles. Biol. Reprod. 17, 584-590. 
Foster, D.L. \& Ryan, K.D. (1979) Mechanisms governing onset of ovarian cyclicity at puberty in the lamb. Annls Biol. anim. Biochem. Biophys. 19, 1369-1380.

Foster, D.L., Karsch, F.J., Olster, D.H., Ryan, K.D. \& Yellon, S.M. (1986) Determinants of puberty in a seasonal breeder. Recent Progr. Horm. Res. 42, $331-384$

Gibori, G., Antczak, E. \& Rothchild, 1. (1977) The role of estrogen in the regulation of luteal progesterone secretion in the rat after day 12 of pregnancy. Endocrinology 100, 1483-1495.

Gonzalez-Padilla, E., Wiltbank, J.N. \& Niswender, G.D. (1975) Puberty in beef heifers. I. The inter-relationship between pituitary, hypothalamic and ovarian hormones. J. Anim. Sci. 40, 1091-1104.

Goodman, R.L. \& Karsch, F.J. (1980) Pulsatile secretion of luteinizing hormone: differential suppression by ovarian steroids. Endocrinology 107, 1286-1290.

Goodman, R.L. \& Karsch, F.J. (1981) The hypothalamic pulse generator: a key determinant of reproductive cycles in sheep. In Biological Clocks in Seasonal Reproductive Cycles, pp. 223-236. Eds B. K. Follett \& D. E. Follett. Wright, Bristol.

Goodman, R.L., Bittman, E.L., Foster, D.L. \& Karsch, F.J. (1981) The endocrine basis of the synergistic suppression of luteinizing hormone by estradiol and progesterone. Endocrinology 109, 1414-1417.

Goodman, R.L., Bittman, E.L., Foster, D.L. \& Karsch, F.J. (1982) Alterations in the control of luteinizing hormone pulse frequency underlie the seasonal variation in estradiol negative feedback in the ewe. Biol. Reprod. 27, 580-589.

Hunter, M.G., Southee, J.A., McLeod, B.J. \& Haresign, W. (1986) Progesterone pretreatment has a direct effect on GnRH-induced preovulatory follicles to determine their ability to develop into normal corpora lutea in anoestrous ewes. J. Reprod. Fert. 76, 349-363.

Karsch, F.J. (1980) Seasonal reproduction: a saga of reversible fertility. The Physiologist 23, 29-38.

Karsch, F.J., Foster, D.L., Bittman, E.L. \& Goodman, R.L. (1983) A role for estradiol in enhancing luteinizing hormone pulse frequency during the follicular phase of the estrous cycle of sheep. Endocrinology 113, 1333-1339.

Keisler, D.H., Inskeep, E.K. \& Dailey, R.A. (1983) First luteal tissue in ewe lambs: influence on subsequent ovarian activity and response to hysterectomy. $J$. Anim. Sci. 57, 150-156.

Legan, S.J. \& Karsch, F.J. (1979) Neuroendocrine regulation of the estrous cycle and seasonal breeding in the ewe. Biol. Reprod. 20, 74-85.

Legan, S.J., Karsch, F.J. \& Foster, D.L. (1977) The endocrine control of seasonal reproductive function in the ewe: a marked change in response to the negative feedback action of estradiol on luteinizing hormone secretion. Endocrinology 101, 818-824.

Legan, S.J., I'Anson, H., Fitzgerald, B.P. \& Fitzovich, D. (1985a) Does the seasonal increase in estradiol negative feedback prevent LH surges in anestrous ewes by suppressing hypothalamic GnRH pulse frequency? Biol. Reprod. 33, 117-131.

Legan, S.J., I'Anson, H., Fitzgerald, B.P. \& Akaydin, M.S., Jr (1985b) Importance of short luteal phases in the endocrine mechanism controlling initiation of estrous cycles in anestrous ewes. Endocrinology 117, 1530-1536.

Levine, J.E., Pau, K.F., Ramirez, V.D. \& Jackson, G.L. (1982) Simultaneous measurement of luteinizing hormone-releasing hormone and luteinizing hormone release in unanesthetized, ovariectomized sheep. Endocrinology 111, 1449-1455.

Martin, G.B., Cognié, Y., Schirar, A., Nunes-Ribeiro, A., Fabre-Nys, C. \& Thiéry, J.-C. (1985) Diurnal variation in the response of anoestrous ewes to the ram effect. J. Reprod. Fert. 75, 275-284.

McLeod, B.J. \& Haresign, W. (1984) Evidence that progesterone may influence subsequent luteal function in the ewe by modulating preovulatory follicle development. J. Reprod. Fert. 71, 381-386.

McLeod, B.J., Haresign, W. \& Lamming, G.E. (1982a) The induction of ovulation and luteal function in seasonal anoestrous ewes treated with small-dose multiple injections of Gn-RH. J. Reprod. Fert. 65, 215-221.

McLeod, B.J., Haresign, W. \& Lamming, G.E. (1982b) Response of seasonally anoestrous ewes to smalldose multiple injections of Gn-RH with and without progesterone pretreatment. J. Reprod. Fert. 65, 223-230.

McNatty, K.P., Ball, K., Gibb, M., Hudson, N. \& Thurley, D.C. (1982) Induction of cyclic ovarian activity in seasonally anoestrous ewes with exogenous GnRH. J. Reprod. Fert. 64, 93-96.

McNeilly, A.S., O'Connell, M. \& Baird, D.T. (1982) Induction of ovulation and normal luteal function by pulsed injection of luteinizing hormone in anestrous ewes. Endocrinology 110, 1292-1299.

Niswender, G.D., Reichert, L.E., Jr, Midgley, A.R., Jr \& Nalbandov, A.V. (1969) Radioimmunoassay for bovine and ovine luteinizing hormone. Endocrinology 84, $1166-1173$.

Oldham, C.M. \& Martin G.B. (1978) Stimulation of seasonally anovular Merino ewes by rams. II. Premature regression of ram-induced corpora lutea. Anim. Reprod. Sci. 1, 291-295.

Pearce, D.T., Martin, G.B. \& Oldham, C.M. (1985) Corpora lutea with a short life-span induced by rams in seasonally anovulatory ewes are prevented by progesterone delaying the preovulatory surge of $\mathbf{L H} . J$. Reprod. Fert. 75, 79-84.

Pope, G.S., Gupta, S.K. \& Munro, I.B. (1969) Progesterone levels in the systemic plasma of pregnant, cycling, and ovariectomized cows. J. Reprod. Fert. 20, 369-381.

Robinson, J.E. \& Karsch, F.J. (1984) Refractoriness to inductive day lengths terminates the breeding season of the Suffolk ewe. Biol. Reprod. 31, 656-663.

Robinson, J.E., Radford, H.M. \& Karsch, F.J. (1985) Seasonal changes in pulsatile luteinizing hormone (LH) secretion in the ewe: relationship of frequency of LH pulses to daylength and response to estradiol negative feedback. Biol. Reprod. 33, 324-334.

Ryan, K.D. \& Foster, D.L. (1978) Two LH surges at puberty in the female lamb: possible role of progesterone. Biol. Reprod. 18, Suppl. 1, 58A, Abstr.

Scaramuzzi, R.J. \& Baird, D.T. (1977) Pulsatile release 
of luteinizing hormone and the secretion of ovarian steroids in sheep during anestrus. Endocrinology 101, 1801-1806.

Snedecor, G.W. \& Cochran, W.G. (1967) Statistical Methods, 6th edn. Iowa State University Press, Ames.

Walton, J.S., McNeilly, J.R., McNeilly, A.S. \& Cunningham, F.J. (1977) Changes in concentrations of follicle-stimulating hormone, luteinizing hormone, prolactin and progesterone in the plasma of ewes during the transition from anoestrus to breeding activity. J. Endocr. 75, 127-136.

Walton, J.S., Evins, J.D., Fitzgerald, B.P. \& Cunningham, F.J. (1980) Abrupt decrease in day- length and short-term changes in the plasma concentrations of FSH, LH and prolactin in anoestrous ewes. J. Reprod. Fert. 59, 163-171.

Yuthasastrakosol, P., Palmer, W.M. \& Howland, B.E. (1975) Luteinizing hormone, oestrogen and progesterone levels in peripheral serum of anoestrous and cyclic ewes as determined by radioimmunoassay. $J$. Reprod. Fert. 43, 57-65.

Yuthasastrakosol, P., Palmer, W.M. \& Howland, B.E. (1977) Release of LH in anoestrous and cyclic ewes. J. Reprod. Fert. 50, 319-321.

Received 26 June 1987 